\title{
The use of digital technology in foreign language learning
}

\author{
Senad Bećirović ${ }^{1}$ D $\cdot$ Amna Brdarević-Čeljo ${ }^{1} \cdot$ Haris Delić $^{1}$
}

Received: 28 March 2021 / Accepted: 2 September 2021 / Published online: 27 September 2021

(c) The Author(s), under exclusive licence to Springer Nature Switzerland AG 2021

\begin{abstract}
Digital technology has become an essential factor in the process of language learning. This quantitative study investigates the use of technology as well as teacher's support in the process of technology-based learning of English as a foreign language (EFL) among high school students in Bosnia and Herzegovina. The data have been collected by the questionnaire modelling teachers' influence on learners' selfdirected use of technology for language learning which consists of seven subscales. The results show that the participants' experience with technology-based language learning (TBL) is rather positive and that teachers have an important role in technology-based foreign language learning, indicating insignificant gender and EFL GPA differences but significant grade level differences on the combined dependent variables of teacher's support. Furthermore, the results revealed insignificant differences on the combined dependent variables of technology use based on the students' gender and grade level but significant differences based on the students' EFL GPA. The findings of this study may assist teachers in engaging students to efficiently use digital technologies in the process of foreign language learning at the high school level.
\end{abstract}

Keywords Technology · Teacher's support · Language learning · Gender · Grade level · EFL GPA

\section{Introduction}

Electronic communication devices, such as computers, laptops, mobile phones, the global communication system, the Internet, and other technologies, namely video and audio conferencing, videotelephony, webcasts and chat rooms, have become an integral part of language instruction and their widespread use in education, and likewise in other public domains, has been steadily increasing. Thus, technologybased learning, as the process of learning by means of electronic technology, has emerged and substantially empowered language learning, making it no longer solely

Senad Bećirović

senad.becirovic@ibu.edu.ba

1 International Burch University, Sarajevo, Bosnia and Herzegovina 
constricted to the traditional school learning environment. It has enormous educational potential both within and beyond the classroom milieu as it allows learners to easily access various instructional materials using different educational platforms, it facilitates learners' exposure to native speakers' lessons and tutorials and their engagement in diverse online courses. The term technology-based learning encloses some related terms, such as "computer-assisted language learning" (CALL) (Afshari et al. 2013), "computer-mediated communication" (CMC) (Sorensen 2013), "information, communication and technology" (ICT) (Ghavifekr and Rosdy 2015), "technology-enabled active learning" (TEAL) (Tong et al. 2018) or "electronic learning" (e-learning) (Liaw et al. 2007) and these terms have been used simultaneously and sometimes interchangeably. Still, the term "technology-based learning" or TBL (as employed in Hsu et al. 2012) will be maintained as a designation in the current research.

Technology-based learning experience entails the students' use of technology and internet facilities, as well as audio-visual aids and equipment, for doing homework assignments, exercises and expanding their knowledge in the subject matter discussed by instructors within the classroom. If students are carefully guided through the process and directed towards the purposeful use of technology, they are on the way to achieving learner's autonomy and becoming autonomous and self-regulated learners. Teachers, who with their instructional practices and role modelling, influence students' intellectual, emotional and social development, play a significant role in that process. They should guide students towards finding their best approach to learning and, creating a positive atmosphere among students while using technology (Yaman and Bećirović 2016), help them develop a capacity to effectively exploit the resources they have and eventually lead them to a self-directed use of technology for out-of-school learning (Lai 2015).

\section{Literature review}

\section{Self-directed learning}

Self-directed learning (SDL), also called self-initiated, self-planned and self-regulated learning, has been defined as the "process in which individuals take the initiative, with or without the help from others, in diagnosing their learning needs, formulating goals, identifying human and material resources, choosing and implementing appropriate learning strategies, and evaluating learning outcomes" (Knowles 1975, p. 18, in Lai 2013, p. 100). Zimmerman (2000), defines it as "a process by which learners direct and coordinate their efforts, thoughts, and feelings in order to achieve their learning goals" (p. 15) or stated in the simplest terms, it is learning beyond a formal institutional setting. The concept of self-directed learning, regarded as one of the most critical personal skills for the twenty-first Century (Eroglu and Ozbek 2018), represents any personal development and increase in knowledge or skill. Even though it is widely used in contemporary research sources, the idea of SDL has its roots in Socrates' emphasis on independent learning and relentless pursuit of the best learning approach (Delić and Bećirović 2016). Socrates, as Beavers (2009) 
points out, "illustrates concisely the concepts of self-directed learning in his discussion with Meno by allowing him to determine the topic of interest (The Great Dialogues of Plato)" (p. 27).

Whenever the concept of self-directed learning or students' individual learning is discussed, the question of the teacher's role is raised. Self-directed learning, even though it supposes a teacher-free environment, is not meant to exclude teachers. On the contrary, self-directed learning as such, should be led and supported by teachers and the teacher's role is to lead students towards developing independent critical thinking and learning skills. Such a teacher-supported concept of self-directed learning is also explained in Sert and Boynuegri's research (2017) stating that "it is clear that self-directed learning requires classroom context in which learner autonomy is promoted by the teacher" (p. 26). Garrison (1997) names a self-directed way of learning as "a collaborative constructivist perspective", explaining that an individual takes responsibility for constructing meaning, while others confirm its worthwhileness, and he states that "the challenge for teachers is to create the educational conditions that will facilitate self-direction" (p. 30).

\section{Technology and self-directed learning}

Technology-based instruction is a subject that has evinced an intense and lively research interest (Clark et al. 2009; Ghavifekr and Rosdy 2015; Paris 2004; Sert and Boynuegri 2017). One of the reasons why technology has become an integral part of today's language learning environment is its ability to provide personalized language instruction and materials enabling learners to select the lesson and adapt it to their needs. Likewise, technology advances access to information and offers more communication possibilities. Using technology devices, such as TV, radio, movies or the Internet in general for the purpose of achieving self-directed learning serves a variety of functions in shaping positive learner identity, maintaining motivation for learning (Lamb 2007), providing learners with a supportive learning community, offering learners a place for self-expression, and enhancing their self-perception (Gao 2009; Teo et al. 2010). It also allows the process of "online informal learning of language" (Toffoli and Sockett 2013, p. 2) to happen.

According to Gokcearslan (2017), the level of self-directed learning is a predictor of the integration of technology. To motivate students to self-directedly use technology for learning, teachers need to use different types of support, such as behavior support (enhancing confidence in their abilities to engage in out-of-class learning activities), capacity support (helping learners to develop the capacity to use the resources effectively), or pedagogical or metacognitive guidance. Lai (2015), reporting the results of the research conducted among 160 university students, states that "affection support predicted self-directed technology use through strengthened perceptions of the usefulness of technological resources for language learning, whereas capacity support and behavior support predicted self-directed technology use through enhanced perceptions of facilitating conditions and self-efficacy in using technological resources for language learning" (p. 81) and then concludes that, in order to successfully lead students towards these goals, teachers need to be skilled in 
explaining broad pedagogical content of technology that goes far beyond the knowledge of using it.

Hence, the use of technology requires a level of self-direction. An individual has to take the initiative and responsibility for what and how he/she uses technology outside the formal educational milieu. Geng et al. (2019) found out that students who are self-directed and share positive attitudes toward technology-based learning are consequently more motivated in adopting online learning strategies and achieving their learning goals (p. 21). Moreover, when using technology to learn, students are more active and autonomous (Demir and Yurdugül 2013; Tawafak et al. 2018). Rashid and Asghar (2016) also found out that technology use predicts self-directed learning and that technology use indirectly impacts academic performance through self-directed learning (p. 609).

However, technology integration per se is not sufficient. According to Yilmaz (2018), there are technical and pedagogical implications in this type of language learning. The former include students' skills in their self-directed use of technology, their effort, and devices, and the latter include instructional design. In other words, there is a need for teachers who are able to organize and maintain this type of lesson flow and who also possess "pedagogical knowledge" (Okojie et al. 2006, p. 67) that needs to be incorporated into such instruction.

Among the factors that lead students towards self-directed learning through the use of technology are their perceptions of its usefulness and benefits for their success. Thus, it has been shown that perceived usefulness (belief in enhanced performance through technological behavior) and attitude to technology use (affective appraisal of the technological behavior) (Clark et al. 2009; Lai et al. 2012) are powerful predictors of the individual's intention to use technology. Hence, Lai and Gu (2011) found out that the usefulness of technology in the process of language learning and the compatibility of its use predicted the frequency of learners' usage of technology to self-moderate their language learning.

Still, attitudes towards technology use and its implementation into the learning processes in schools are both positive and negative. Ghavifekr and Rosdy (2015) state that the benefits of information, communication, and technology (ICT) programs are the development of confidence, better communication, creativity and imagination and they also indicate that "ICT helps students to possess all four skills in learning when they are able to acquire necessary information and knowledge" (p. 188). Though research in this field clearly shows that technology stimulates the learning process and maximizes the abilities of students in active learning (Jorge et al. 2003; Young 2003), technology-based learning entails that both students and schools are facilitated with computers and internet access, which does not seem to be always the case. Thus, even if technology is affordable and not very expensive, there still exist schools, especially in rural areas, which lack adequate equipment and internet access. Moreover, technical problems and teachers' lack of experience, and, not rarely, confidence to use technology, impede this way of learning as well (Jamieson-Proctor et al. 2013). This leads to teachers' negative attitudes about technology use and their beliefs that the class cannot be easily controlled when the technology-based instruction is implemented (Ghavifekr and Rosdy 2015). The conclusion that can be drawn from the aforementioned is that teachers with negative attitudes 
towards technology are unlikely to transfer their skills to students and encourage them to use it. Thus, to effectively incorporate technology-based learning into the learning processes, proper equipment needs to be supplied and teachers, schools and students need to have sufficient knowledge to use it as well.

\section{Teachers' role in technology-based self-directed learning}

Teachers have always performed a key role in education (Ahmetović et al. 2020). With today's unlimited information content on the Internet and students' readiness to access it, teachers, apart from only teaching, should also be mentoring their students in their process of self-directed learning (Hassan and Mirza 2020). Liaw et al. (2007) reported that technology-based learning is "autonomous and rich in multimedia" (p. 1076), and that students expect their teachers to assist them when using an e-learning environment. Since, according to Albirni (2006), "teachers are the most important agents of change within the classroom arena" (p. 374), the process of effective technology-based education without teachers' adequate skill and dedication will not be successful even if schools are sufficiently equipped with sophisticated technology. Given the fact that teachers determine what the lesson will look like, and thus how technology will be used and implemented during lessons, studies indicate that the successful application of educational technologies relies largely on the educators' attitudes. Thus, Kersaint et al. (2003) reported that teachers who have a positive attitude toward technology use incorporate it into their teaching more comfortably. Similarly, Bullock (2004) states that the teacher's attitude is a major enabling factor in students' adoption of technology.

Thus, the teacher's role in implementing technology into the learning processes is of paramount importance and such support is highly beneficial. According to Sorensen (2013), "the way a teacher feels about technology, whether consciously or not, is sure to affect their implementation of the curriculum, and those attitudes frequently filter down to their students" (p. 24). Ghavifekr and Rosdy (2015) found out that teachers who supported technology-led instructions make learning more effective and that students are more active and engaged in the lesson prepared by such teachers. Lai and Li (2011) also emphasizes the importance of teachers' conscious effort through various formats, for example, providing information on useful technological aids and resources and guiding students on how to use specific technological resources.

Deepwell and Malik (2008) also emphasize the role of tutors in informing and guiding students through their study. These authors indicated that $76 \%$ of their interviewees reported that they use technology for self-directed learning, but at the same time they did not work on their studies independently and they expected immediate feedback from their tutors, and felt very frustrated when they did not receive it ( $\mathrm{p}$. 11). Teaching behavior and teachers' social relations to their students are, according to Mahini et al. (2012), some of the most influential factors of the teacher's performance in classrooms. Jensen et al. (2019) conclude that the student-teacher social element affects students' engagement, motivation, and learning outcomes. 
The current situation created by past and ongoing worldly pandemic has posed a major challenge to educational institutions at all levels around the world and likewise in Bosnia and Herzegovina. The teaching process has completely shifted from classrooms to students' homes with the use of different technological devices and online meeting platforms as basic instructional tools. This required a change in methods of teaching as well as in the instructional materials, which needed to be adapted to this new mode. Students were also under pressure to get accustomed to those modes, looking for new ways to do projects, homework assignments, and to increase their class participation. All these circumstances, accompanied by occasional internet connection problems, have led to students' aiming to become better self-directed learners and search for information, do tasks and exercises on their own. Due to the fact that teachers were also striving to get used to that unexpected situation, their role as a mediating factor in students' self-directed learning was seen as something of less importance. Therefore, in this study, Bosnian EFL learners' perceptions of this type of learning as well as of how teacher behavior and support affected their self-directed use of technology for language learning were surveyed.

\section{Methodology}

Given the importance of technology-based learning and the teacher's support in implementing it, this study aims at investigating the Bosnian students' technology use in learning English as a foreign language and their perceptions of teachers' support in that respect based on their gender, grade level and EFL GPA. Based on the aim of the study, the following hypotheses have been tested:

1. There will be a significant difference in teachers' affection, capacity, and behavior support for the technology use in foreign language learning based on students' gender,

2. There will be a significant difference in teachers' affection, capacity, and behavior support for the technology use in foreign language learning based on students' grade level,

3. There will be a significant difference in students' perceived usefulness, computer self-efficacy, facilitation condition, and technology use in foreign language learning based on gender,

4. There will be a significant difference in students' perceived usefulness, computer self-efficacy, facilitation condition, and technology use in foreign language learning based on their grade level,

5. There will be a significant difference in teachers' affection, capacity, and behavior support for the technology use in foreign language learning based on students' EFL GPA scores,

6. There will be a significant difference in students' perceived usefulness, computer self-efficacy, facilitation condition, and technology use in foreign language learning based on students' EFL GPA score. 
Table 1 Gender, grade level, and average course grade of the participants

\begin{tabular}{|c|c|c|c|c|c|c|}
\hline & $n$ & $\%$ & & & $n$ & $\%$ \\
\hline Gender & & & & $\begin{array}{l}\text { Average course } \\
\text { grade }\end{array}$ & & \\
\hline Male & 73 & 42.2 & 1 & Negative & 2 & 1.2 \\
\hline Female & 100 & 57.8 & 2 & Sufficient & 24 & 13.9 \\
\hline Grade & & & 3 & Good & 35 & 20.2 \\
\hline First & 75 & 43.4 & & & & \\
\hline Second & 36 & 20.8 & 4 & Very good & 36 & 20.8 \\
\hline Third & 19 & 11.0 & 5 & Excellent & 76 & 43.9 \\
\hline Fourth & 43 & 24.9 & & & & \\
\hline Total & 173 & 100 & & & 173 & 100 \\
\hline
\end{tabular}

\section{Participants}

The research sample in the current study was composed of 173 Bosnian high school students studying at four different grade levels. The convenience sampling method was employed in the process of participants' selection. The sample consisted of 100 female students (57.8\%) and 73 male students (42.2\%). As for the grade level, there were 75 first grade students (43.4\%), 36 s grade students (20.8\%), 19 third grade students $(11 \%)$ and 43 fourth grade students (24.9\%), with the age range between 15 and 19. The participants also provided information on their grade-point average obtained in the English as a foreign language (EFL) course. The grades ranged between 1 and 5, with 1 being a non-passing grade and 5 being the highest grade. Thus, 76 participants obtained the GPA score 5, 36 participants the GPA score 4, 35 participants the GPA score 3, and 24 participants the GPA score 2, while only 2 participants obtained a non-passing grade 1 , and, as such, this group will not be included in the analysis. Table 1 provides all the details related to the participants.

\section{Instruments and procedures}

The questionnaire Modeling teachers' influence on learners' self-directed use of technology for language learning employed in this research was developed and validated by Lai (2015). It contains 30 items with response options ranging from 1 to 5 on a 5 -point Likert scale $(1=$ Strongly agree, $2=$ agree, $3=$ Neutral, $4=$ Disagree, $5=$ Strongly disagree). The questionnaire is composed of seven subscales, namely affection support (e.g. My language teacher encourages us to use technology for language learning outside the classroom), capacity support (e.g. My language teacher shares with us useful technological resources/sites/tools for language learning outside the classroom), behavior support (e.g. My language teacher often uses technological resources or tools in her/his classes), technology use (e.g. I use technology to expand opportunities to use the language), perceived usefulness (e.g. technology enhances my language learning outcomes), computer self-efficacy (e.g. I am confident with my abilities in using technologies effectively for language learning) 
Table 2 Reliability indices

\begin{tabular}{lll}
\hline & $N$ of items & $\begin{array}{l}\text { Cron- } \\
\text { bach's } \\
\text { alpha }\end{array}$ \\
\hline Affection support & 2 & .69 \\
Capacity support & 2 & .78 \\
Behavior support & 3 & .74 \\
Technology use & 7 & .85 \\
Perceived usefulness & 6 & .82 \\
Computer self-efficacy & 3 & .75 \\
Facilitation conditions & 3 & .55 \\
\hline
\end{tabular}

and facilitation condition (e.g. I have the resources necessary to use technologies for language learning). Concerning the data related to the EFL GPA, regular grades assigned by EFL teachers which are based on the students' evaluation have been utilized. According to the Bosnian grading system, 1 is the lowest (failing) grade and 5 indicates the highest achievement (excellent).

The questionnaire was delivered to the students in an online form following the explanation of the nature and purpose of the study. The students were asked to complete the questionnaire anonymously and without any time limits. Cronbach's alpha was employed to assess the reliability of the instrument and the coefficient amounted to $\alpha=0.89$ for all the items, which is a good reliability index (Pallant 2007). Each subscale was assessed for internal consistency using Cronbach's alpha. The results showed acceptable consistency and reliability, as displayed in Table 2.

\section{Data analysis}

The collected data were analyzed using the Statistical Package for Social Sciences (SPSS, v. 26). Pearson product correlation coefficients as well as the descriptive analysis including means, standard deviation $(S D)$ and frequencies were employed. One-way MANOVA was used to investigate the differences in technology use and teacher's support based on gender, grade level and GPA groups.

\section{Results}

\section{Preliminary analysis}

The participants scored quite high on the perceived usefulness of technological resources for foreign language learning $(M=2.04, S D=.60)$ and are confident about their abilities to use technology in the process of foreign language learning $(M=2.25, S D=.67)$. Furthermore, the participants stated that they have positive conditions to use technology $(M=2.21, S D=.70)$ and they scored quite high on computer self-efficacy $(M=2.25, S D=.72)$ (Table 3$)$. The teacher's support for the use of technology was rated slightly above 2 , with affection support being most 
Table 3 Descriptive statistics and correlation

\begin{tabular}{llllllllll}
\hline & $n$ & $M$ & $S D$ & 1 & 2 & 3 & 4 & 5 & 6 \\
\hline 1. Affection support & 173 & 2.28 & .91 & & & & & \\
2. Capacity support & 173 & 2.53 & 1.05 & $.57^{* *}$ & & & & & \\
3. Behavior support & 173 & 2.38 & .87 & $.60^{* *}$ & $.62^{* *}$ & & & & \\
4. Technology use & 173 & 2.25 & .67 & $.28^{* *}$ & $.20^{* *}$ & $.30^{* *}$ & & & \\
5. Perceived usefulness & 173 & 2.04 & .60 & $.20^{* *}$ & $.19^{*}$ & $.27^{* *}$ & $.68^{* *}$ & & $.04^{* *}$ \\
6. Computer self-efficacy & 173 & 2.25 & .72 & $.22^{* *}$ & $.19^{*}$ & $.21^{* *}$ & $.56^{* *}$ & $.64^{* *}$ \\
7. Facilitation condition & 173 & 2.21 & .70 & $.15^{*}$ & $.17^{*}$ & $.25^{* *}$ & $.40^{* *}$ & $.50^{* *}$ & $.53^{* *}$ \\
\hline
\end{tabular}

*Correlation is significant at the 0.05 level (2-tailed)

**Correlation is significant at the 0.01 level (2-tailed)

highly rated $(M=2.28, S D=.91)$, behavior support closely following $(M=2.38$, $S D=.87)$, and capacity support receiving the lowest rating $(M=2.53, S D=1.05)$. The participants scored the highest mean on the perceived usefulness $(M=2.04$, $S D=.60)$ and facilitation condition subscales $(M=2.21, S D=.70)$. In terms of the use of technology $(M=2.25, S D=.67)$ and computer self-efficacy $(M=2.25$, $S D=.72$ ), the same mean score was measured.

A Pearson product-moment correlation coefficient was computed to assess the relationship between dependent variables. The results showed a significant correlation between affection support and capacity support $(r=.57, n=173, p<.001)$, affection support and behavior support $(r=.60, n=173, p<.001)$ as well as between behavior support and capacity support $(r=.62, n=173, p<.001)$ (Table 3$)$. Furthermore, a Pearson product-moment correlation coefficient showed that the use of technology significantly correlated with perceived usefulness $r=.68, n=173, p<.001$, computer self-efficacy $r=.54, n=173, p<.001$ and facilitation condition $r=.40$, $n=173, p<.001$. A significant correlation was also measured between perceived usefulness and computer self-efficacy $r=.64, n=173, p<.001$ as well as between perceived usefulness and facilitation condition $r=.50, n=173, p<.001$.

The first hypothesis was related to gender-based differences in the participants' opinions on the support they receive from teachers in the process of technologybased foreign language learning.

A one-way MANOVA was conducted to determine gender differences on the combined dependent variables of teacher's support (affection, capacity, and behavior support) in the process of technology-based foreign language learning. The results indicated that gender did not significantly affect the combined dependent variables of teacher's support, Wilks's Lambda $\lambda=0.995, F(3,168.000)=0.300, p=.826$, $\eta^{2}=.005$. Likewise, there were no significant gender-based differences on the affection support subscale Wilks's Lambda $\lambda=0.995, F(3,168.000)=0.300, p=.560$, $\eta^{2}=.002$, capacity support subscale Wilks's Lambda $\lambda=0.995, F(3,168.000)=0.300$, $p=.350, \eta^{2}=.005$, and behavior support subscale Wilks's Lambda $\lambda=0.995, F(3$, $168.000)=0.300, p=.474, \eta^{2}=.003$. The results are displayed in Table 4.

The second hypothesis was related to grade-related differences in the participants' views on teacher's support in the process of technology-based foreign language 
Table 4 Multivariate ANOVA of teacher's support based on gender

\begin{tabular}{llllllll}
\hline & \multicolumn{2}{l}{ Male } & & \multicolumn{2}{l}{ Female } & $p$ & $\eta^{2}$ \\
\cline { 2 - 3 } & $M$ & $S D$ & & $M$ & $S D$ & & \\
\hline Affection support & 2.23 & .90 & 2.32 & .92 & .560 & .002 \\
Capacity support & 2.44 & .97 & 2.59 & 1.10 & .350 & .005 \\
Behavior support & 2.32 & .92 & 2.42 & .84 & .474 & .003 \\
\hline
\end{tabular}

learning. A one-way MANOVA revealed a significant influence of grade level on the combined dependent variables of teacher's support, Wilks's Lambda $\lambda=0.904$, $F(9,406.585)=1.923, p=.047, \eta^{2}=.033$, with small effect size. Univariate ANOVA indicated that grade level had a significant influence only on the behavior support subscale, $F(3,3.048)=4.180, p=.007, \eta^{2}=.069$ with moderate effect size (Table 5) while capacity support $F(3,1.881)=1.728, p=.163, \eta^{2}=.030$ and affection support $F(3,1.683)=2.059, p=.108, \eta^{2}=.035$ were insignificantly affected by grade level. As for the differences among four grade levels, the first grade reported the highest mean value for each of the three teacher support scales.

A one-way MANOVA was employed to determine the influence of gender on the combined dependent variables related to educational technologies, namely perceived usefulness, computer self-efficacy, facilitation condition, and technology use. The results showed that gender did not significantly affect the combined dependent variables related to educational technologies Wilks's Lambda $\lambda=0.515$, $F(4,168.000)=0.988, p=.724, \eta^{2}=.012$. The analysis of variance on each of the educational technologies subscales showed that there were no significant genderbased differences: the perceived usefulness subscale Wilks's Lambda $\lambda=0.936, F(1$, $.001)=.002, p=.966, \eta^{2}=.000$, computer self-efficacy subscale Wilks's Lambda $\lambda=0.936, F(1, .058)=.002, p=.740, \eta^{2}=.001$, facilitation condition subscale Wilks's Lambda $\lambda=0.936, F(1, .639)=1.298, p=.256, \eta^{2}=.008$, and technology use subscale $\lambda=0.936, F(1, .042)=.093, p=.761, \eta^{2}=.001$.

As displayed in Table 6, both male $(M=2.05, S D=.59)$ and female $(M=2.04$, $S D=.62)$ participants achieved the highest score on the perceived usefulness subscale and the results point to a rather low score on the computer self-efficacy subscale achieved by males $(M=2.23, S D=.70)$ and females $(M=2.27, S D=.74)$. On the other hand, males achieved a rather high score on the facilitation condition subscale $(M=2.14, S D=.58)$ while the scores achieved by females were not as high $(M=2.26, S D=.77)$.

Table 5 Multivariate ANOVA of teacher's support based on grade level

\begin{tabular}{|c|c|c|c|c|c|c|c|c|c|c|}
\hline & \multicolumn{2}{|c|}{ Grade 1} & \multicolumn{2}{|c|}{ Grade 2} & \multicolumn{2}{|c|}{ Grade 3} & \multicolumn{2}{|c|}{ Grade 4} & \multirow[t]{2}{*}{$p$} & \multirow[t]{2}{*}{$\eta^{2}$} \\
\hline & $M$ & $S D$ & $M$ & $S D$ & $M$ & $S D$ & $M$ & $S D$ & & \\
\hline Affection support & 2.15 & .96 & 2.24 & .80 & 2.24 & .88 & 2.57 & .87 & .108 & .035 \\
\hline Capacity support & 2.37 & .96 & 2.50 & 1.28 & 2.50 & .94 & 2.83 & .99 & .163 & .030 \\
\hline Behavior support & 2.32 & .84 & 2.07 & .72 & 2.37 & .93 & 2.74 & .92 & .007 & .069 \\
\hline
\end{tabular}


Table 6 Multivariate ANOVA of technology use based on gender

\begin{tabular}{|c|c|c|c|c|c|c|}
\hline & \multicolumn{2}{|l|}{ Male } & \multicolumn{2}{|c|}{ Female } & \multirow[t]{2}{*}{$p$} & \multirow[t]{2}{*}{$\eta^{2}$} \\
\hline & $M$ & $S D$ & $M$ & $S D$ & & \\
\hline Technology use & 2.27 & .67 & 2.24 & .67 & .761 & .001 \\
\hline Perceived usefulness & 2.05 & .59 & 2.04 & .62 & .966 & .000 \\
\hline Comp. self-efficacy & 2.23 & .70 & 2.27 & .74 & .740 & .001 \\
\hline Facilitation condition & 2.14 & .58 & 2.26 & .77 & .256 & .008 \\
\hline
\end{tabular}

A one-way MANOVA was also conducted to determine the influence of grade level on the combined dependent variables related to educational technologies (namely perceived usefulness, computer self-efficacy, facilitation condition, and technology use). The results revealed that grade level did not have a significant influence on combined variables related to educational technologies Wilks's Lambda $\lambda=0.936, F(12,439.485)=1.923, p=.518, \eta^{2}=.022$. Further research demonstrated that no significant grade level differences were found on the perceived usefulness subscale $\lambda=0.936, F(12,439.485)=1.923, p=.878, \eta^{2}=.004$, computer self-efficacy subscale $\lambda=0.936, F(12,439.485)=1.923, p=.718$, $\eta^{2}=.008$, technology use subscale $\lambda=0.936, F(12,439.485)=1.923, p=.193$, $\eta^{2}=.028$ and facilitation condition subscale $\lambda=0.936, F(12,439.485)=1.923$, $p=.450, \eta^{2}=.015$.

The perceived usefulness subscale was rated with the highest mean by all grade levels while in other subscales there were variations between grade levels. Thus, the technology use subscale was rated with a high mean score by grade 1 and the mean score decreased in other grades. The computer self-efficacy and facilitation condition subscales were rated almost identically by the students at all grade levels (Table 7).

A one-way MANOVA was conducted to determine the teachers' support for technology use (affection support, capacity support and behavior support) and the differences existing among four EFL GPA groups. The results indicated an insignificant difference among EFL GPA groups on the combined dependent variables of teachers' support, Wilks's Lambda $\lambda=0.933, F(12,439.486)=.975, p=.472$, $\eta^{2}=.023$.

Furthermore, there were no significant differences among EFL GPA groups on the affection support subscale Wilks's Lambda $\lambda=0.933, F(12,439.486)=.975$,

Table 7 Multivariate ANOVA of technology use based on grade level

\begin{tabular}{|c|c|c|c|c|c|c|c|c|c|c|}
\hline & \multicolumn{2}{|c|}{ Grade 1} & \multicolumn{2}{|c|}{ Grade 2} & \multicolumn{2}{|c|}{ Grade 3} & \multicolumn{2}{|c|}{ Grade 4} & \multirow[t]{2}{*}{$p$} & \multirow[t]{2}{*}{$\eta^{2}$} \\
\hline & $M$ & $S D$ & $M$ & $S D$ & $M$ & $S D$ & $M$ & $S D$ & & \\
\hline Technology use & 2.16 & .66 & 2.21 & .70 & 2.46 & .83 & 2.37 & .54 & .193 & .028 \\
\hline Perceived usefulness & 2.05 & .61 & 1.97 & .69 & 2.09 & .61 & 2.07 & .52 & .878 & .004 \\
\hline Comp. self-efficacy & 2.23 & .80 & 2.17 & .67 & 2.32 & .84 & 2.34 & .54 & .718 & .008 \\
\hline Facilitation condition & 2.28 & .73 & 2.05 & .76 & 2.25 & .56 & 2.21 & .63 & .450 & .015 \\
\hline
\end{tabular}


Table 8 Multivariate ANOVA of teacher's support based on EFL GPA score

\begin{tabular}{|c|c|c|c|c|c|c|c|c|c|c|}
\hline \multirow[t]{2}{*}{ EL GPA } & \multicolumn{2}{|c|}{$5(n=76)$} & \multicolumn{2}{|c|}{$4(n=36)$} & \multicolumn{2}{|c|}{$3(n=35)$} & \multicolumn{2}{|c|}{$2(n=24)$} & \multirow[t]{2}{*}{$p$} & \multirow[t]{2}{*}{$\eta^{2}$} \\
\hline & $M$ & $S D$ & $M$ & $S D$ & $M$ & $S D$ & $M$ & $S D$ & & \\
\hline Affection support & 2.29 & .89 & 2.56 & .92 & 2.20 & .87 & 2.06 & .91 & .063 & .052 \\
\hline Capacity support & 2.49 & 1.02 & 2.82 & 1.09 & 2.51 & 1.15 & 2.31 & .84 & .213 & .034 \\
\hline Behavior support & 2.31 & .85 & 2.66 & .97 & 2.40 & .88 & 2.19 & .71 & .162 & .038 \\
\hline
\end{tabular}

Table 9 Multivariate ANOVA of technology use based on EFL GPA score

\begin{tabular}{|c|c|c|c|c|c|c|c|c|c|c|}
\hline \multirow[t]{2}{*}{ EL GPA } & \multicolumn{2}{|c|}{$5(n=76)$} & \multicolumn{2}{|c|}{$4(n=36)$} & \multicolumn{2}{|c|}{$3(n=35)$} & \multicolumn{2}{|c|}{$2(n=24)$} & \multirow[t]{2}{*}{$p$} & \multirow[t]{2}{*}{$\eta^{2}$} \\
\hline & $\bar{M}$ & $\overline{S D}$ & $\bar{M}$ & $\overline{S D}$ & $\bar{M}$ & $\overline{S D}$ & $\bar{M}$ & $\overline{S D}$ & & \\
\hline Technology use & 2.21 & .63 & 2.34 & .70 & 2.26 & .66 & 2.33 & .74 & .253 & .031 \\
\hline Perceived usefulness & 1.89 & .54 & 2.10 & .69 & 2.10 & 54 & 2.38 & .64 & .011 & .075 \\
\hline Comp. self-efficacy & 2.12 & .70 & 2.15 & .71 & 2.40 & .60 & 2.65 & .83 & .012 & .074 \\
\hline Facilitation condition & 2.04 & .61 & 2.16 & .73 & 2.33 & .68 & 2.65 & .77 & .003 & .091 \\
\hline
\end{tabular}

$p=.063, \eta^{2}=.052$, capacity support subscale Wilks's Lambda $\lambda=0.995, F(3$, $168.000)=0.300, p=.213, \eta^{2}=.034$ and behavior support subscale Wilks's Lambda $\lambda=0.995, F(3,168.000)=0.300, p=.162, \eta^{2}=.038$.

As can be seen in Table 8, the highest mean score by each EFL GPA group was reported for the affection support subscale while the lowest mean again by each EFL GPA group was reported for the capacity support subscale. Moreover, the highest mean was reported by the EFL GPA score 2 on two subscales, namely the affection support and behavior support subscales.

A one-way MANOVA was also conducted to determine the influence of the participants' EFL GPA scores on the combined dependent variables related to educational technologies, namely perceived usefulness, computer self-efficacy, facilitation condition, and technology use. The results indicated significant differences among EFL GPA groups on the combined dependent variables related to educational technologies, Wilks's Lambda $\lambda=0.788, F(16,504.721)=2.565, p=.001, \eta^{2}=.058$, with a small effect size (Table 9).

Significant EFL GPA-related differences were found in perceived usefulness Wilks's Lambda $\lambda=0.936, F(12,439.485)=1.923, p=.011, \eta^{2}=.075$ with a moderate effect size, computer self-efficacy Wilks's Lambda $\lambda=0.936, F(12$, $439.485)=1.923, p=.012, \eta^{2}=.074$ also with a moderate effect size and facilitation condition Wilks's Lambda $\lambda=0.936, F(12,439.485)=1.923, p=.003$, $\eta^{2}=.091$, with a moderate effect size. The differences in technology use among four different EFL GPA groups were insignificant, Wilks's Lambda $\lambda=0.936, F(12$, 439.485) $=1.923, p=.253, \eta^{2}=.031$.

The mean scores for the technology use subscale were similar among all EFL GPA score groups. However, the highest mean score for the three other subscales (perceived usefulness, computer self-efficacy and facilitation condition) was 
reported by the EFL GPA group 5 and then the mean scores for all these subscales decreased as the EFL GPA scores decreased so that the lowest mean scores were reported by the EFL GPA group 2 (Table 9).

\section{Discussion}

The focus of the present study was on analyzing high school students' perceptions of technology-based language learning and their connection to language achievement and the students' gender and grade level, as well as the students' perceptions and attitudes towards teachers' support in that process. The analysis revealed that the participants shared rather positive perceptions towards the use of technology for the purpose of language learning.

Thus, the first research hypothesis predicting that there will be a significant difference in the teacher's support of the use of technology based on gender was refuted as the main effects of all dependent variables were insignificant and male and female participants shared rather similar opinions on teacher's support and its three types. More specifically, the male participants seem to share more positive opinions on all three subscales of teacher's support than females and the results indicate that the highest mean value was measured on the affection support subscale and the lowest mean value on the capacity support subscale, which is in line with Lai's research (2015). The teacher's support overall was found to be of high importance to the participants, which strengthens the argument that students still rely on traditional teacher-centered approaches. Teachers should guide students towards a proper use of technology in the process of language learning. Furthermore, being able to raise students' awareness of contemporary language learning processes (Carson and Mynard 2012), teachers can provide methodological information on learning resources and strategies and be actively engaged in tracking their progress.

The second hypothesis predicting significant differences in the teacher's support of the use of technology in the classroom based on grade level was supported as the impact of grade level differences on the combined dependent variables of teacher's support was significant. However, the impact of grade level on individual subscales of teacher's support varied and the impact of grade level proved to be significant only on the behavior support subscale. The teacher's support was reported as an important factor in this type of learning, and, as stated in Mahini et al. (2012), the teacher's role is to facilitate and monitor and direct the learning process. As demonstrated by Vajzović et al. (2019), a large number of primary and high school Bosnian teachers $(57 \%)$ strongly agree that knowledge, skills and competencies acquired through media and information literacy are of high importance in modern times, but there are still some teachers, though a small percentage of them (1.2\%), who disagree with that view. Rather interestingly, the participants of the study conducted by Vajzović et al. (2019) also admitted that they might lack some competencies related to teaching some content in the field of media and information literacy. Therefore, there should be more research studies related to teachers' readiness to assist and help students in using technology for language learning. This also implies that teachers, especially those who have recently been introduced to technology-based teaching, 
should include some follow-up development activities in their professional development programs (Albert et al. 2014). According to Ahmadi (2018), teachers' support of technology-integrated curriculum should increase the actual use of technology in learning.

The third hypothesis was also refuted as no significant differences were found in the students' perceived usefulness, computer self-efficacy, facilitation condition and technology use based on their gender, which further supports the argument that technology, as an information source, can be used by everyone, regardless of gender differences. The results obtained for gender-related differences in terms of technologybased learning are supported by some previous findings. Thus, Demir and Yurdugül (2013) as well as Jaleel and Anuroofa (2017) did not find any significant differences in students' self-directed technology-based learning in terms of gender. Likewise, Çelik et al. (2012) found no statistically significant differences regarding male and female participants' use of ICT for self-regulated learning. The current study is also aligned with Eroglu and Ozbek (2018), who found out that students' self-directed technology-based learning and students' attitude towards e-learning do not differ in terms of gender (p. 305), as well as with Gokcearslan (2017), who reported that no meaningful difference was found in the level of self-directed learning with technology in terms of gender. Contrary to current study findings, some research revealed significant gender-related differences in perceptions, motivation, and usefulness of this type of learning (e.g. Chyung 2007; Idrizi et al. 2020; Sullivan 2001). Thus, Idrizi et al. (2020) found out that male students are more linked to technology use in general while female students achieved a greater academic success in subjects in which technology was employed. Analyzing male and female college students' experience in an online environment, Sullivan (2001) also reported significant differences between the way male and female students perceived the online learning environment, self-discipline, and self-motivation.

Self-efficacy, as one of the variables examined in the technology use analysis and found to be insignificantly different for male and female participants, was also researched in Chyung (2007) and the author found out that female students improved their self-efficacy significantly more and scored significantly higher on the final exam than male students. Almost identical conclusions were drawn by Perkowski (2012), who reported that female students performed better in performance achievement and self-efficacy in online learning environments. In another research on selfefficacy, a significant amount of variance in male students' achievement was determined by their self-efficacy and task value (Yukselturk and Bulut 2009).

Some conflicting findings related to gender differences were also reported when students' attitudes towards technology-based learning were researched. Hence, Suri and Sharma (2013) and Paris (2004) pointed to statistically insignificant genderrelated differences, whereas Ong and Lai (2006) found that gender differences in attitudes towards technology-based learning were significant and that male participants achieved a higher mean on computer self-efficacy, perceived usefulness, perceived ease of use, and behavioral intention than females (p. 823). Moreover, a similar investigation was done by Long (2015), who found that female students reported a greater knowledge and readiness of technology usage. 
The fourth hypothesis was also refuted as no significant differences were found in the students' perceived usefulness, computer self-efficacy, facilitation condition and technology use based on their grade level. Students' perceptions or perceived usefulness of technology in language learning is their belief that using a particular tool will enhance their performance (Davis 1989). Afshari et al. (2013) found out that students' positive perceptions towards technology-based language learning (perceived usefulness) had a direct and significant effect on students' attitudes towards this learning concept, indicating that the improvement in students' perceptions of computer attributes causes enhancement in their attitudes (p. 858), which is not corroborated by the current study findings. Similar conclusions can be drawn from Hismanoglu (2012), who indicated that one of the determinants of students' acceptance of technology is their perceived usefulness or attitude towards it.

Lai (2013) points out that educational compatibility and perceived usefulness were the two major factors that mediated most of the relationships that affected technology use (p. 86). Similarly, Yilmaz (2018) found out that self-directed learning with technology sufficiency has the most important effect on learners' will to use it. In other words, the more they use it successfully, its usage grows rapidly. Yilmaz (2018) continues that, in order to increase students' acceptance of technological tools, it is necessary to increase self-directed learning with technology competencies and academic motivation (p. 97). Dahlstrom (2012) investigated students' perceptions of the usefulness of technology too and determined that over half of all the research participants believe they are more actively involved in courses in which technology is used and that technology contributes to them feeling connected to other students, their teachers, and their institutions (p. 10). Thus, direct relations of grade level differences in terms of the technology use conditions were not found in the literature. As a pioneer in this type of research concern, especially in the case of Bosnian high school students, this research can just confirm the previously stated claim that in this rather new concept of learning, the students' differences do not seem to be a significant factor.

The fifth hypothesis predicted that there will be a statistically significant difference in the teacher's affection, capacity, and behavior support for technology use in foreign language learning based on the participants' GPA in English as a foreign language and it was refuted since the students' GPA in English as a foreign language did not significantly influence the combined dependent variables of teachers' support or the teacher's affection, capacity and behavior support for technology use in foreign language learning individually. Such results are in line with Bello's (2014) research results which showed no relationship between teachers' level of technology implementation and student achievement. However, some studies emphasized that the impact of technology on student achievement might be dependent on teachers' usage and students' motivation (Norris and Soloway 2010). More precisely, Tang and Austin (2009) maintained that technology and the professors' effective usage of technology cause an improvement in students' learning performance or their GPA (p. 1244). Such research findings indicate that students with high GPA favor the use of technology and that professors' effective use of technology and their gender are effective predictors of their grades. 
The last hypothesis stating that there will be a significant difference in the students' perceived usefulness, computer self-efficacy, facilitation condition and technology use in foreign language learning based on their EFL GPA score was supported as the participants' EFL GPA score significantly impacts the combined variables of technology use as well as some of them individually, namely the perceived usefulness, computer self-efficacy and facilitation condition. Thus, the students with the highest GPA in English (5 or excellent) achieved the highest mean on all variables and the mean values on all the subscales decreased with a decrease in the students' EFL GPA. This confirmed the assumptions that the highest achieving EFL students would use technology for the purpose of learning and show greater readiness to use it than lower achieving students, who seem to be using technology much less. This supports the findings of Little-Wiles et al. (2014), who concluded that the students who visited online learning platforms less frequently obtained lower grades than other students. The current study findings hence are aligned with the findings of several other studies which have confirmed that exposure to technology has a positive impact on students' achievement (Bello 2014; Neill and Mathews 2009; Suhr et al. 2010), specifically in mathematics and language arts (Neill and Mathews 2009). However, the majority of existing literature in the field of technology-based learning does not connect it to students' learning performance or success. Language proficiency is, according to Domingo (2019), affected by language exposure, or by lesson study or a research-based approach (Kıncal et al. 2019). Al-Bataineh et al. (2016) state that, even though technology could be an influential factor in students' academic achievement, it is still not a sole factor when it comes to official tests and measurements (p. 380). Furthermore, investigating students' access to virtual learning environments (VLE), Chowdhry et al. (2014) found out that this way of learning did not affect the students' academic performance (p. 13). Similarly, Rashid and Asghar's (2016) research findings reported that, even though the use of technology has a direct positive relationship with students' engagement and self-directed learning, an insignificant direct effect was found between technology use and students' academic performance.

Students' success, or more specifically, their learning performance, seems to be more related to their learning styles (Delić 2018; Mašić et al. 2020), learning strategies they employ (Akay and Anvarovich 2015; Bećirović et al. 2018; Delić and Bećirović 2018), their personal characteristics or their educational milieu (Bećirović and Brdarević-Čeljo 2018; Bećirović et al. 2019; Fiossi-Kpadonou 2017; Kovačević et al. 2018) and less to the mode of teaching. Bartholomew et al. (2017), for example, found out that, in a middle-school sample study, students' self-directed learning correlated more closely with the characteristics of students and classroom than with access to technology tools (p. 20). Similarly, Long (2015) found out that technologyrelated variables of his investigation were not significant factors impacting students' final course grades.

\section{Conclusion}

The current study has discussed the high school students' perceptions of technologybased English language learning as well as their perceptions of teacher's support in that process, with a special focus on the impact of gender, grade level and EFL achievement 
on both. Some general conclusions can be drawn from the obtained results, namely (1) high school students are very positive about the use of technology and teacher's support in the process of foreign language learning (2) gender has no significant effect on the students' use of technology and teacher's support in the process (3) the students' grade level significantly impacts their perceptions of teacher's support in the process of technology-based learning, while it does not significantly impact their perceived usefulness of technology (4) on the contrary, students' EFL achievement does not have a significant effect on their perceptions of teacher's support, while it significantly impacts their perceived usefulness of technology.

The current study findings emphasize the need to raise teachers' awareness of the support to be given to students to help them increase their self-directed usage of technology, particularly so outside the official school environment. The education system should follow this development and adequately respond to it and systemic reforms need to be made. This can only be addressed with an adequate, systemic, long-term, feasible and sustainable approach to media and information literacy in the educational system of Bosnia and Herzegovina. Due to the fact that the data for this research were collected at the time when the teaching process was completely online-based and very much affected by the ongoing Covid 19 pandemic and taking into consideration that such a situation will persist at least to some extent, this kind of research displays originality and innovativeness and has a potential to provide some novel perspectives and solutions to the ensuing problems in the social and cultural space of Bosnia and Herzegovina.

Still, there are some limitations in this research which should be properly addressed in any further research in this field. Firstly, the sample of only high school students limits the possibility of making in-depth comparisons with primary and university-level education. Secondly, the focus of the current study is the use of technology and teacher's support in language learning, English language learning in particular, and some of the key factors impacting both might differ across different fields. In some other fields, different types of teacher's support might be more relevant.

Funding Authors confirm that they did not receive any financial contributions or funding from any third party for this research.

Data availability Raw data that support this study may be available with restrictions. The datasets generated and/or analyzed during the current study are available from the corresponding author on reasonable request.

\section{Declarations}

Conflict of interest The authors declare no competing interest for this study.

Informed consent Informed consent has been obtained from all participants involved in the study.

\section{References}

Afshari M, Ghavifekr S, Siraj S, Jing D (2013) Students' attitudes towards computer-assisted language learning. Procedia Soc Behav Sci 103:852-859. https://doi.org/10.1016/j.sbspro.2013.10.407 
Ahmadi RA (2018) The use of technology in English language learning. Intl J Res Engl Educ 3(2):115125. https://doi.org/10.29252/ijree.3.2.115

Ahmetović E, Bećirović S, Dubravac V (2020) Motivation, anxiety and students' performance. Eur J Contemp Educ 9(2):271-289. https://doi.org/10.13187/ejced.2020.2.271

Akay C, Anvarovich A (2015) Description of learning strategies and socio-cultural background influence on the productive skills of Turkish and Bosnian students. J Educ Hum Dev. https://doi.org/10.15640/ jehd.v4n1a19

Al-Bataineh A, Harris J, Al-Bataineh M (2016) One to one technology and its effect on student academic achievement and motivation. Contemp Educ Technol. https://doi.org/10.30935/cedtech/6182

Albert J, Blanchard MR, Kier MW, Carrier SJ (2014) Supporting teachers' technology integration: a descriptive analysis of social and teaching presence in technical support sessions. J Technol Teach Educ 22(2):137-165

Albirini A (2006) Teachers' attitudes toward information and communication technologies: the case of Syrian EFL teachers. Comput Educ 47(4):373-398. https://doi.org/10.1016/j.compedu.2004.10.013

Bartholomew S, Reeve E, Veon R, Goodridge W, Lee V, Nadelson L (2017) Relationships between access to mobile devices, student self-directed learning, and achievement. J Technol Educ. https:// doi.org/10.21061/jte.v29i1.a.1

Beavers A (2009) Teachers as learners: implications of adult education for professional development. J Coll Teach Learn (TLC). https://doi.org/10.19030/tlc.v6i7.1122

Bećirović S, Brdarević-Čeljo A (2018) Exploring and assessing cross-cultural sensitivity in Bosnian tertiary education: is there a real promise of harmonious coexistence? Eur J Contemp Edu 7(2). https:// doi.org/10.13187/ejced.2018.2.244

Bećirović S, Brdarević-Čeljo A, Dubravac V (2018) The effect of nationality, gender, and GPA on the use of reading strategies among EFL university students. SAGE Open 8(4):1-12. https://doi.org/10. $1177 / 2158244018809286$

Bećirović S, Brdarević-Čeljo A, Zavrl I (2019) Research into intercultural effectiveness in a multicultural educational milieu in Bosnia and Herzegovina. Econ Res 32(1):1336-1351. https://doi.org/10.1080/ 1331677X.2019.1629329

Bello AA (2014) Impact of technology interventions on student achievement in rural Nigerian schools. Retrieved from https://scholarworks.waldenu.edu/dissertations

Bullock D (2004) Moving from theory to practice: an examination of the factors that preservice teachers encounter as they attempt to gain experience teaching with technology during field placement experiences. J Technol Teach Educ 12(2):211-237

Carson L, Mynard J (2012) Introduction. In: Mynard J, Carson L (eds) Advising in language learning: dialogue, tools and context. Pearson Education Limited, Harlow

Çelik S, Arkin E, Sabriler D (2012) EFL learners' use of ICT for self-regulated learning. J Lang Linguist Stud 8(2):98-118

Chowdhry S, Sieler K, Alwis L (2014) A study of the impact of technology-enhanced learning on student academic performance. J Perspect Appl Acad Pract 2(3):3-15. https://doi.org/10.14297/jpaap.v2i3. 111

Chyung S (2007) Age and gender differences in online behavior, self-efficacy, and academic performance. Q Rev Distance Educ 8(3):213-222

Clark W, Logan K, Luckin R, Mee A, Oliver M (2009) Beyond Web 2.0: mapping the technology landscapes of young learners. J Comput Assist Learn 25:56-69. https://doi.org/10.1111/j.1365-2729. 2008.00305.x

Dahlstrom E (2012) ECAR study of undergraduate students and information technology (Research Report). CO: EDUCAUSE Center for Appl Res. Lousville

Davis FD (1989) Perceived usefulness, perceived ease of use and user acceptance of information technology. MIS Q 13:319-340. https://doi.org/10.2307/249008

Deepwell F, Malik S (2008) On campus, but out of class: an investigation into students' experiences of learning technologies in their self-directed study. ALT J Res Learn Technol 16(1):5-14. https://doi. org/10.1080/09687760701850166

Delić H (2018) The analysis of learning styles among high school students. J Educ Humanit 2(2):17-28. https://doi.org/10.14706/jeh2018123

Delić H, Bećirović S (2016) Socratic method as an approach to teaching. Eur Res 111(10):511-517. https://doi.org/10.13187/er.2016.111.511

Delić H, Bećirović S (2018) The influence of grade point average and socioeconomic status on learning strategies. J Educ Humanit 1(2):53-64. https://doi.org/10.14706/jeh2018123 
Demir Ö, Yurdugül H (2013) Self-directed learning with technology scale for young students: a validation study. E-Int J Educ Res 4(3):58-73

Domingo P (2019) Correlation between the students' English language proficiency and their exposure to English language. SSRN Electron J. https://doi.org/10.2139/ssrn.3462970

Eroglu M, Özbek R (2018) The investigation of the relationship between attitudes towards e-learning and self-directed learning with technology of secondary school students. Int Online J Educ Sci 10(5):297-314. https://doi.org/10.15345/iojes.2018.05.019

Fiossi-Kpadonou E (2017) Self-esteem, personal characteristics and school performance. Int J Contemp Res Rev 25:2-5

Gao XS (2009) The 'English corner' as an out-of-class learning activity. ELT J 63:60-67

Garrison DR (1997) Self-directed learning: toward a comprehensive model. Adult Educ Q 48(1):18-33

Geng S, Law K, Niu B (2019) Investigating self-directed learning and technology readiness in a blending learning environment. Int J Educ Technol High Educ. https://doi.org/10.1186/s41239-019-0147-0

Ghavifekr S, Rosdy WAW (2015) Teaching and learning with technology: effectiveness of ICT integration in schools. Int J Res Educ Sci (IJRES) 1(2):175-191

Gokcearslan S (2017) Perspectives of students on acceptance of tablets and self-directed learning with technology. Contemp Educ Technol 8(1):40-55. https://doi.org/10.30935/cedtech/6186

Guglielmino LM (2013) The case for promoting self-directed learning in formal educational institutions. SA-eDUC 10(2):1-18

Hassan M, Mirza T (2020) Impact of ICT in changing the role of a teacher: an overview. Gedrag Organ Rev 33(3):441-449. https://doi.org/10.37896/gor33.03/440

Hismanoglu M (2012) Prospective EFL teachers' perceptions of ICT integration: a study of distance higher education in Turkey. Educ Technol Soc 15(1):185-196

Hsu Y, Ho HNJ, Tsai C, Hwang G, Chu H, Wang C, Chen N (2012) Research trends in technology-based learning from 2000 to 2009: a content analysis of publications in selected journals. J Edu Technol Soc 15(2): 354-370

Idrizi E, Filiposka S, Trajkovik V (2020) Gender differences in online learning. Conference: ICT innovations 2020 web proceedings, at: online conference.

Jaleel S, Anuroofa OM (2017) A study on the relationship between self-directed learning and achievement in information technology of students at secondary level. Univ J Educ Res 5(10):1849-1852

Jamieson-Proctor R, Albion P, Finger G, Cavanagh R, Fitzgerald R, Bond T, Grimbeek P (2013) Development of the TTF TPACK survey instrument. Aust Educ Comput 27(3):26-35

Jensen L, Price L, Roxå T (2019) Seeing through the eyes of a teacher: differences in perceptions of HE teaching in face-to-face and digital contexts. Stud High Educ 45(6):1149-1159. https://doi.org/10. 1080/03075079.2019.1688280

Jorge CMH, Gutiérrez ER, García EG, Jorge MCA, Díaz MB (2003) Use of the ICTs and the perception of e-learning among university students: a differential perspective according to gender and degree year group. Interact Educ Multimedia 7:13-28

Kersaint G, Horton B, Stohl H, Garofalo J (2003) Technology beliefs and practices of mathematics education faculty. J Technol Teach Educ 11(4):549-577

Kıncal R, Ozan C, İleritürk D (2019) Increasing students' English language learning levels via lesson study. Engl Lang Teach 12(9):88-95. https://doi.org/10.5539/elt.v12n9p88

Knowles, M (1975) Self-directed learning: a guide for learners and teachers, New York, Association Press

Kovačević F, Brdarević-Čeljo A, Bećirović S (2018) Opportunities and challenges facing Bosnian highschool EFL learners. Eur Res 9(4):298-306. https://doi.org/10.13187/er.2018.4.298

Lai C (2013) A framework for developing self-directed technology use for language learning. Lang Learn Technol 17(2):100-122

Lai C (2015) Modeling teachers' influence on learners' self-directed use of technology for language learning outside the classroom. Comput Educ 82:74-83. https://doi.org/10.1016/j.compedu.2014. 11.005

Lai C, Gu MY (2011) Self-regulated out-of-class language learning with technology. Comput Assist Lang Learn 24:317-335. https://doi.org/10.1080/09588221.2011.568417

Lai C, Li G (2011) Technology and task-based language teaching: a critical review. CALICO Journal 28(2): 498-521

Lai C, Wang Q, Lei J (2012) What factors predict undergraduate students' use of technology for learning? A case from Hong Kong. Comput Edu 59(2):569-579. https://doi.org/10.1016/j.compedu.2012.03. 006 
Lamb M (2007) The impact of school on EFL learning motivation: an Indonesian case study. TESOL Q 41:757-780. https://doi.org/10.1002/j.1545-7249.2007.tb00102.x

Liaw SS, Huang HM, Chen GD (2007) Surveying instructor and learner attitudes toward e-learning. Comput Educ 49(4):1066-1080. https://doi.org/10.1016/j.compedu.2006.01.001

Little-Wiles J, Fernandez E, Fox P (2014) Understanding gender differences in online learning. In: 2014 IEEE Frontiers in Education Conference (FIE), pp 1-4. https://doi.org/10.1109/FIE.2014.7044069

Long M (2015) Second language acquisition and task-based language teaching. Wiley Blackwell

Mahini F, Forushan Z, Haghani F (2012) The importance of teacher's role in technology-based education. Procedia Soc Behav Sci 46:1614-1618. https://doi.org/10.1016/j.sbspro.2012.05.348

Mašić A, Polz E, Bećirović S (2020) The relationship between learning styles, GPA. Sch Lev Gend Eur Res 11(1):51-60. https://doi.org/10.13187/er.2020.1.51

Neill M, Mathews J (2009) Does the use of technological interventions improve student achievement in mathematics and language arts for an identified group of at-risk middle school students? Southeastern Teacher Edu 2(1):57-65

Norris C, Soloway E (2010) One-to-one computing has failed our expectations. Dist Adm 46(5):58-69

Okojie M, Olinzock A, Okojie-Boulder T (2006) The pedagogy of technology integration. J Technol Stud 32(2):66-71. https://doi.org/10.21061/jots.v32i2.a.1

Ong CH, Lai JY (2006) Gender differences in perceptions and relationships among dominants of e-learning acceptance. Comput Hum Behav 22(5):816-829. https://doi.org/10.1016/j.chb.2004.03.006

Pallant J (2007) SPSS survival manual: a step-by-step guide to data analysis using SPSS for windows, 3rd edn. McGraw Hill Open University Press, Maidenhead

Paris PG (2004) E-learning: a study on secondary students' attitudes towards online web assisted learning. Int Educ J 5(1):98-112

Perkowski J (2012) The role of gender in distance learning: a meta-analytic review of gender differences in academic performance and self-efficacy in distance learning. J Educ Technol Syst 41(3):267-278. https://doi.org/10.2190/ET.41.3.e

Rashid T, Asghar HM (2016) Technology use, self-directed learning, student engagement and academic performance: examining the interrelations. Comput Hum Behav 63:604-612. https://doi.org/10. 1016/j.chb.2016.05.084

Sert N, Boynuegri E (2017) Digital technology use by the students and English teachers and self-directed language learning. World J Educ Technol Curr Issues 9(1):24-34. https://doi.org/10.18844/wjet. v9i1.993

Sorensen MM (2013) Student attitudes toward social media technology as an enhancement to language acquisition. All Theses and Dissertations. 3783.

Suhr KA, Hernandez DA, Grimes D, Warschauer M (2010) Laptops and fourth-grade literacy: assisting the jump over the fourth-grade slump. J Technol Learn Assess 9(5):1-46

Sullivan P (2001) Gender differences and the online classroom: male and female college students evaluate their experiences. Community College J Res and Practice 25:805-818

Suri G, Sharma S (2013) The impact of gender on attitude towards computer technology and e-learning: an exploratory study of Punjab University. India Int J Eng Res 2(2):132-136

Tang TLP, Austin MJ (2009) Students' perceptions of teaching technologies, application of technologies, and academic performance. Comp Edu 53(4):1241-1255

Tawafak R, Romli A, Arshah R, Almaroof R (2018) Assessing the impact of technology learning and assessment method on academic performance: review paper. EURASIA J Math Sci Technol Educ 14(6):2241-2254. https://doi.org/10.29333/ejmste/87117

Teo T, Tan SC, Lee CB, Chai CS, Koh JHL (2010) The self-directed learning with technology scale (SDLTS) for young students: an initial development and validation. Comput Educ 55(4):1764-1771. https://doi.org/10.1016/j.compedu.2010.08.001

Toffoli D, Sockett G (2013) University teachers' perceptions of Online Informal Learning of English (OILE). Comput Assist Lang Learn 28(1):7-21. https://doi.org/10.1080/09588221.2013.776970

Tong V, Standen A, Sotiriou M (2018) Shaping higher education with students. Retrieved from www.ucl. ac.uk/ucl-press

Vajzović, E, Turčilo E, Cerić H, Osmić A, Silajdžić L (2019) Uvođenje medijske i informacijske pismenosti u obrazovni sistem - procjena kompetencija nastavnika za podučavanje medijske i informacijske pismenosti u Kantonu Sarajevo [Introducing media and information literacy to the educational system - assessment of teachers 'competence for teaching media and information literacy in Sarajevo Canton]. Sarajevski žurnal za društvena pitanja 8:131-163 
Yaman A, Bećirović S (2016) Learning English and media literacy. Imp J Interdiscip Res (IJIR) 2(6):660-663

Yilmaz R (2018) Self-directed learning with technology and academic motivation as predictors of tablet PC acceptance. In: Khan A, Umair S (eds) Handbook of research on mobile devices and smart gadgets in K-12 education. Information Science Reference, Hershey

Young SC (2003) Integrating ICT into second language education in a vocational high school. J Comput Assist Learn 19:447-461. https://doi.org/10.1046/j.0266-4909.2003.00049.x

Yukselturk E, Bulut S (2009) Gender differences in self-regulated online learning environment. Educ Technol Soc 12(3):12-22

Zimmerman BJ (2000) Attaining self-regulation: a social cognitive perspective. In: Boekaerts M, Pintrich PR, Zeidner M (eds) Handbook of self-regulation: theory, research, and applications. Academic Press, San Diego, pp 13-39 